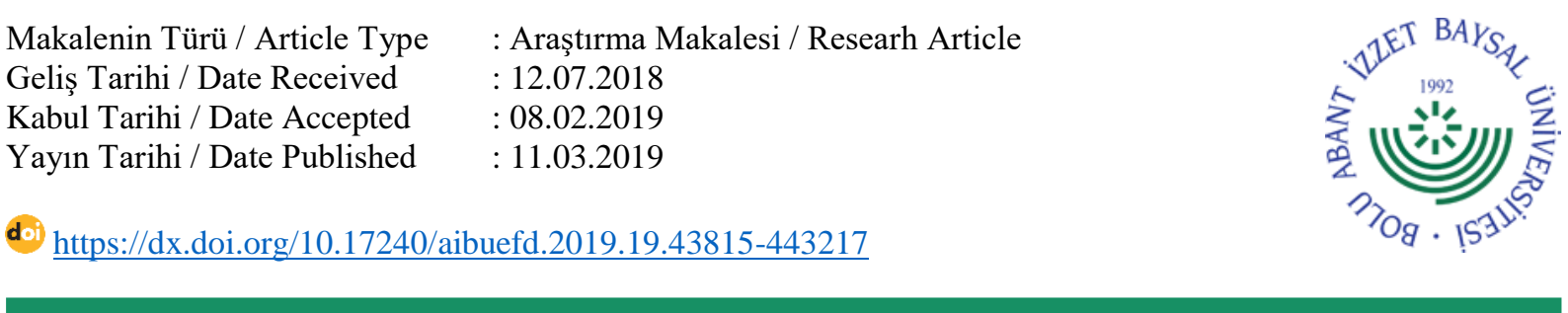

\title{
OKULÖNCESİ ÇOCUKLARINDA DOĞA ALGISI
}

\author{
Nilüfer KÖŞKER ${ }^{1}$
}

\section{ÖZ}

Erken çocukluk dönemi doğa sevgisi ve doğa bilincinin kazandırılacağı kritik bir dönemdir. Erken yaşlarda doğa ile etkileşim; çocuğun sağlıklı gelişiminin yanı sıra doğaya karşı farkındalık, bağlılık ve ekolojik sorumluluğun gelişmesi açısından olumlu sonuçlara yol açmaktadır. Bu çalışmanın amacı, okul öncesi çocuklarının doğayı nasıl algıladıklarını belirlemektir. Araştırmanın verileri okulöncesi eğitim kurumlarına devam eden 100 çocuktan toplanmıştır. Araştırmada veri toplamak için çocuklar tarafından çizilen doğa resimleri ve yarı yapılandırılmış görüşme tekniği kullanılmıştır. Görüşme verileri ve çocukların çizdikleri resimler, nitel veri analiz yöntemlerinden içerik analizi kullanılarak çözümlenmiştir. Araştırmadan elde edilen bulgulara göre çocuklar için doğa, hayvanların ve bitkilerin bulunduğu, insan yaşamının dışında, uzakta bir ortamdır. Doğadaki temel ilişkiler hakkında yeterli bir algı düzeyinde bulunmayan çocuklar, daha çok nesne odaklı bir doğa anlayışına sahiptirler. Bu bağlamda sınıf ve okul dışı doğa etkinliklerinin okul öncesi öğretim programının içeriğine dâhil edilmesi ve doğanın çocuk için bu deneyimler yoluyla bir öğrenme ve yaşam alanı haline dönüştürülmesi önerilmektedir.

Anahtar Kelimeler: Doğa, çocuk, doğa algısı, doğa sevgisi, doğa eğitimi

\section{PRE-SCHOOL CHILDREN'S PERCEPTIONS OF NATURE}

\begin{abstract}
Early childhood is a critical time for the inculcation of the love and consciousness of nature. Interaction with nature at an early age leads to positive results in terms of healthy development of the child as well as of the awareness, commitment and ecological responsibility towards nature. The purpose of the current study is to determine how pre-school children perceive nature. The data of the current study were collected from 100 children attending pre-school education institutions. In order to collect the data in the current study, drawings of nature produced by the children and a semi-structured interview form were used. The interview data and paintings drawn by the children were analyzed by means of content analysis. The findings of the study revealed that for the children, nature is a place where there are plants and animals, which is distant from human life. The children who were found to have not enough level of perception of the relationships in nature mostly have the objectoriented perception of nature. In this regard, it is suggested that out of class and school activities should be incorporated into pre-school curriculums and that nature should be turned into an area of learning and living through these experiences.
\end{abstract}

Keywords: Nature, child, nature perception, love of nature, nature education

\footnotetext{
${ }^{1}$ Kırlkkale Üniversitesi, Eğitim Fakültesi, niluferkosker@gmail.com, 는ttps://orcid.org/0000-0002-0134-4724
} 


\section{GíRiş}

Günümüz dünyasında kendisini doğanın dışında, ona hükmeden bir varlık olarak konumlandıran insan, bu bilinç ile doğadan ve onun bir parçası olduğu fikrinden uzaklaşmıştır. Özellikle sanayi devrimi ile başlayan ve kentleşmenin hızla geliştiği süreçte doğa, gelişen toplumların ihtiyaçlarını karşılayan bir kaynak olarak insan merkezli bir anlayışın metası haline dönüşmüştür. Bu anlayış, tüketime odaklanmış toplumsal yaşam ile birlikte; harcanan, sömürülen ve insan yaşamına ait bir nesne haline getirilen doğanın dengesinin bozulmasına, hem insan yaşamının geleceğini hem de diğer canlıları tehdit eden çeşitli çevre sorunlarının ortaya çıkmasına zemin hazırlamıştır. Ortaya çıkan çevre sorunlarıyla birlikte, bireylerde ekolojik bilinci geliştirmek ve sorunların çözümünde aktif katılımı sağlamak amacıyla çevre koruma projeleri devreye sokulmuştur. Böylece insanın doğayı hükmü altına alması ve sömürmesi yönündeki anlayışta nesne konumunda olan doğa, ortaya çıkan çevre sorunlarıyla birlikte korunması gereken bir nesne haline dönüşmüştür. Dolayısıyla, doğaya hükmeden ve onu sömüren bir anlayıştan, sürdürülebilirliği sağlamak için koruma anlayışına geçilmiştir (Köşker ve Çalışandemir, 2015). Ancak bu koruma anlayışı, tüketime yönelik bir sürdürülebilirliği değil doğadaki unsurlar ve ilişkilerin devamlılığı açısından bir sürdürülebilirliği hedeflemediği ve ekolojik bir bilince dönüşemediği sürece, doğanın, yani tüm canlılar ve insanın geleceği açısından yeterli olmayacaktır. Çünkü insan, artık doğayla iç içe yaşayan değil, bitmek-tükenmek bilmeyen arzu ve istençleriyle çeşitli yaşamsal formları hayata geçirmek adına, doğaya hükmeden bir beşeri düzen oluşturmakta ve en önemlisi de bunu ciddi çevresel tahribatlar yaparak devam ettirmektedir (Özgen, 2018).

Doğaya yönelik ekolojik bilinç geliştirmede eğitim önemli bir role sahiptir. Ekolojik bilince sahip bireyler yetiştirmek amacıyla gerçekleştirilecek doğa eğitiminin, bireylerin tutum ve davranışlarını şekillendirmesi beklenir. Bu noktada öncelikli adım bireylerin doğaya ilişkin algılarının tespit edilmesidir. Bireyin içinde yaşadığı dünyaya ilişkin algıları, tutum ve davranışlarına temel oluşturmaktadır. Algıların oluşması ve şekillenmesinde ise bireyin kendi dışındaki dünya ile kurduğu ilişkiler ve deneyimleri etkin rol oynamaktadır. Deneyimleri yoluyla çevresini anlamlandıran insan, algılarının temellendirdiği bir takım eylemlerde bulunur. Doğduğu andan itibaren bireyin yaşadığ 1 kültürel ve doğal çevrede kazandığ deneyimler, tutum ve davranışlarını şekillendirmede önemli bir role sahiptir. Kahyaoğlu'na (2015) göre, çocuklar doğumlarından itibaren üç önemli ortamın etkisi altındadır. Bunlar insan topluluklarının oluşturduğu ve şekillendirdiği iktisadi ve sosyo-kültürel ortam (toplumsal çevre), yaşamını sürdürdüğü ve etkilediği doğal ortam (fiziksel çevre), gelenek-görenek, felsefi, dinsel ve etik normların şekillendirdiği içsel ortam (psikolojik çevre)'dır. Eğitim bu üç ortamı birden kapsayan süreç özelliği ile bireylerin bakış açılarını şekillendirmekte ve tutumların kaynaklandığı zemini beslemektedir. Bu bağlamda erken çocukluk dönemi, çocukluktan yetişkinliğe doğru taşınacak bir takım tutum ve davranışların belirlendiği, bireyin bilişsel, duyuşsal ve toplumsal gelişimi açısından kritik önem taşıyan bir dönem olarak karşımıza çıkmaktadır. Erken yaşlarda bireyin kendisiyle, çevresiyle, doğayla yaşadığı olumlu deneyimler, dünyayı değerlendiriş biçiminin temellerini oluşturacaktır (Kesicioğlu ve Alisinanoğlu, 2009). Dolayısıyla erken çocukluk döneminden itibaren yürütülecek doğa eğitimi etkinlikleri, doğa algısının oluşumunda ve şekillenmesinde önemli rol oynayacaktadır.

Erken çocukluk dönemi, çocukların temel kavramları ve bilimsel süreç becerilerini kazandıkları deneyimlerle dolu bir dönemdir. Çocukların bu dönemde yaşadıkları deneyimler, bilginin yapı taşları olarak nitelendirilen kavramların kazanılması için uygun ortam oluşturur (Kıldan ve Pektaş, 2009). Bu dönemde, gelişimsel özellikleri nedeniyle oldukça meraklı olan çocuklar onları çevreleyen dünya hakkında sorular sorarak ve araştırmalar yaparak çevreyi keşfetmeye çalışırlar. Çocukların bu özellikleri, çevre ile ilgili yeterli bilgi edinebilmelerine, olumlu tutum ve davranış geliştirebilmelerine temel oluşturur (Yaşar, İnal, Kaya ve Uyanık, 2012). Çocuklar en erken yaşlardan başlayarak görebildiği, dokunabildiği, duyabildiği dolayısıyla duyularını kullanabildiği, merak ettiği, gözlemleyebildiği ve test edebildiği bir ortamda, çok daha hızlı ve aktif bir öğrenme gerçekleştirebilir (Erentay ve Erdoğan, 2009). Sınıf dışındaki ortamlar bu anlamda öğrenme için büyük firsatlar sunmaktadır. Froebel'e göre ilk yaşlardan itibaren çocuk ile doğa arasında ilişki kurulmalıdır, çünkü bu çocuğun bedeni, zihni ve ahlaki gelişimi için gereklidir (Akt. Akyüz, 1979). Dolayısıyla doğa etkinlikleri yoluyla farkındalık ve sevgi geliştirilerek doğa bilincinin temeli oluşturulacak aynı zamanda çocuğun fiziksel, bilişsel, sosyal ve duygusal gelişimi desteklenecektir. Aksine günümüzde ise çocuklar daha çok kapalı mekânlara çekilmektedir. Migliarese (2008), tarafından "kapalı mekân çocukları" ya da "dijital yerliler" olarak adlandırılan bu çocuklar, doğadan ve doğal bilinçten uzak bir şekilde yaşamaktadırlar. Doğa bilinci, çocuğun yaşam çevresinde bulunan doğal öğe ve mekân kullanımıyla kazandırılmalıdır. Günümüzde ele alındığı biçimiyle doğa eğitiminin okulda öğretilmesi düşüncesi, yaşamın içinde bir uygulamayı içermediğinden yetersiz kalmaktadır (Çukur ve Özgüner, 2008). Sınıfa hapsolmuş, doğanın kendisi yerine görüntüleri üzerinden nesne odaklı, deneyime dayanmayan öğretim etkinlikleri ile ekolojik bilinci hedefleyen bir eğitim gerçekleştirmek mümkün görünmemektedir. Özellikle çocukların merak duyguları ile beslenen etkinlikler, doğanın ve doğadaki ilişki düzenin anlaşılması bakımından önem taşımaktadır. Çocuğun doğal unsurlar ve bunlar arasındaki ilişkiyi öğrenebilmesi doğayı tanımasına bağlıdır. Doğada gerçekleştirilecek bir eğitimde, bütün duyularını kullanarak 
edindiği deneyimler çocuğa farkındalık kazandıracak, sonrasında ise ekolojik bilincin temelini oluşturacak tutum ve davranışlara dönüşecektir. Doğa ile erken yaşta tanışma, çocuğun gelişimi açısından önemli bir ihtiyaç olduğu gibi, doğanın yaşamlarının bir parçası olduğunun da farkındalığını sağlayacaktır (Köşker ve Çalışandemir, 2015). Bu nedenle "doğanın dilinin öğretilmesi" şeklinde tanımlanabilen (Ozaner, 2004) doğa eğitimi (nature education), çevre eğitiminden (environmental education) farklı niteliklere sahiptir. Doğal yaşama verilen zararlar, bunun neden ve sonuçları, doğa eğitiminin çevre eğitimiyle kesiştiği önemli bir kavşak noktasını oluşturmaktadır (Özdemir, Akfirat ve Adıgüzel, 2009). Ancak doğa eğitimi bununla birlikte doğrudan deneyimlerle doğanın, doğadaki unsurlar arasındaki ilişkilerin ve süreçlerin farkındalığının sağlanması, doğa sevgisinin ve duyarlılığının geliştirilmesi amaçlarını da içermekte ve bu niteliği ile çevre eğitiminden farklılaşmaktadır. Türkiye'de doğa eğitimi genellikle çevre eğitimi ile karıştırılmaktadır (Çukur ve Özgüner, 2008; Kahyaoğlu, 2016). Ülkemizde okulöncesi dönem çocuklarına yönelik doğa eğitimi çalışmaları (Akköse, 2008; Ogelman, 2012; Öztürk-Aynal, 2013; Yağc1, 2016) yeterli düzeyde değildir. Çalışmalar sıklıkla çevrenin korunması ve sürdürülebilirliğine ilişkin çevre eğitimine (Aydın ve Aykaç, 2016; Çabuk, 2001; Gülay, 2011; Kesicioğlu ve Alisinanoğlu, 2009; Onur, Çağlar ve Salman, 2016; Sungurtekin, 2001; Taşkın ve Şahin, 2008; Tosun ve Demir, 2018; Yaşar, İnal, Kaya ve Uyanık, 2012) odaklanmış durumdadır. Okul öncesi eğitim programı incelendiğinde ise çevre eğitimine yönelik amaç, kazanım, kavram ve belirli gün-haftaların az sayıda yer aldığı, çevre eğitimi ile ilişkili olan bölümlerin öz bakım becerileri alanında olduğu tespit edilmiştir (Demir ve Yalçın, 2014; Gülay ve Ekici, 2010; MEB, 2013). Doğrudan doğa deneyimlerine yönelik bir kazanım ise tespit edilmemiştir (MEB, 2013). Bu bağlamda okulöncesi eğitim programının doğa algısını biçimlendirme, doğal ilişkiler ve süreçlere yönelik farkındalık ve duyarlılıkları geliştirebilme bakımından yetersiz olduğu söylenebilir. Oysa ki erken yaşlarda doğa ile etkileşimin sağlanması, bireylerin doğaya karşı farkındalık, bağlılık ve sevgi geliştirmeleri, ekolojik sorumluluğun gelişmesi açısından olumlu sonuçlara yol açmaktadır (Ballantyne ve Packer, 2002; Chawla, 2006; Civelek ve Akamca, 2017; Keliher, 1997; Louv, 2010; Özdemir, 2010). Dolayısıyla çocukların doğa algılarının belirlenmesi; doğayla bütünleşik bir eğitim içeriğinin ve sürecinin tasarlanması ve uygulanması bakımından ihtiyaçları ortaya çıkararak önemli firsatlar sunacaktır. Böylece algıların olumlu tutum ve davranışlara dönüştürülmesi ve doğaya olan ilginin kalıcı hale gelmesi mümkün olabilecektir.

\subsection{Araştırmanın Amacı}

$\mathrm{Bu}$ araştırmada okul öncesi yaş grubunda bulunan çocukların doğa algılarını belirlemek amaçlanmıştır. Bu amaç doğrultusunda aşağıdaki sorulara cevap aranmıştır:

1- Okul öncesi çocuğu doğa kavramını nasıl algılamaktadır?

2- Okul öncesi çocuğunun doğadaki unsurları tanımlama durumu nedir?

3- Okul öncesi çocuğunun doğa deneyimleri nelerdir?

\section{YÖNTEM}

Araştırmada, çocukların doğa algılarının çizdikleri resimler ve görüşmeler yoluyla ayrıntılı olarak belirlenmesi amaçladığından nitel durum çalışması (case study) deseni kullanılmıştır. Durum çalışması, gerçek yaşam, güncel bir durum ya da durumlar hakkında araştırmacıların detaylı ve derinlemesine bilgi topladığı nitel bir yaklaşımdır (Creswell, 2013). Bu bağlamda çocukların doğa algılarına ilişkin durumun ortaya çıkarılması, yorumlanması, bu duruma yol açan nedenlerin değerlendirilmesi ve ortaya çıkan sonuçlarının tartışılması mümkün olacaktır.

\section{1.Çalışma Grubu}

Araştırmanın çalışma grubunu 2016-2017 eğitim- öğretim döneminde Kırıkkale il merkezindeki resmî okul öncesi kurumlarında ( 2 anaokulu ve 3 anasınıfi) öğrenim gören 100 çocuk oluşturmaktadır. Çalışma grubunun belirlenmesinde amaçlı örneklem yöntemi kullanılmış ve hem ifade becerisi hem de algılama düzeyi göz önünde bulundurularak altı yaş grubundaki çocuklar çalışmaya dâhil edilmiştir. Çalışma grubuna ulaşmak amacıyla öncelikle İl Milli Eğitim müdürlüğünden izin yazısı alınmıştır. Resmi okullarda görevli okul öncesi öğretmenleri ve okul yöneticileri ile görüşülmüş ve araştırma hakkında bilgilendirilen velilerden izin alınmıştır. Veli onayı bulunan ve katılıma istekli olan çocuklar araştırma sürecine dâhil edilmiştir. Çalışma grubunu oluşturan çocukların \%53'ü kız, \% 47'si ise erkeklerden oluşmaktadır.

\subsection{Verilerin Toplanması ve Analizi}

Araştırmada veri toplamak amacıyla çocuklar tarafından çizilen doğa resimleri ve yarı yapılandırılmış görüşme tekniği kullanılmıştır. Araştırmada öncelikle çocuklara "doğa denildiğinde aklınıza ne geliyor" sorusu yöneltilerek, araştırmacı tarafından verilen kâğıtlara (A4) "doğa” resimleri çizmeleri istenmiştir. Böylece görüşme sorularının, çocukların doğa resimlerine etki etmemesi amaçlanmıştır. Resmi çizmeleri için 30 dakika 
süre verilmiştir. Çocuklar resimlerini çizerken araştırmacı ve öğretmen sınıfta bulunmuştur. Çocuk resimlerinin başlıca önemi, çocuğun düşünce şeklini ve içeriğini yansıtmasıdır (Yavuzer, 2009). Resim çizimi, çocuğun kendi görüş ve deneyimlerini eğlenceli ve keyifli bir şekilde ifade edebilmesi için bir yöntem olarak kullanılır (FargasMalet, McSherry, Larkin ve Robinson, 2010). Ancak çocuklar tarafindan çizilmiş resimlerin yetişkinler tarafından yorumlanması/analiz edilmesi çeşitli problemleri ortaya çıkarabilir. Bu türden problemlerin ortadan kalkması için çocuklarla çizdikleri resimler hakkında konuşma yapılmalıdır (Leonard, 2006, s. 64). Bu nedenle resimlerin çocukların bakış açısıyla yorumlanması için, her bir çocukla görüşme yapılmış ve çocukların çizdikleri resmi anlatmaları istenmiştir. Çocukların ifadeleri her bir katılımcı için hazırlanmış olan veri toplama formuna kaydedilmiştir.

İkinci olarak araştırmacı tarafından yarı yapılandırılmış görüşme tekniği uygulanarak her çocukla birebir görüşmeler gerçekleştirilmiş ve yine her çocuk için oluşturulan formlara çocukların yanıtları yazılmıştır. Görüşmeler sırasında çocukların doğa algılarını belirlemek amacıyla açık uçlu sorular yöneltilmiştir. Ayrıca soruların çocuklar tarafından daha iyi anlaşılmasını sağlamak ve çocuklardan gelen yanıtları derinleştirmek için "neden, niçin, ne zaman, neresi vb.” sorular sorulmuştur. Çalışmada çocuklara aşağıdaki sorular yöneltilmiştir:

1. Sana göre doğa ne demektir?

2. Doğada neler var?

3. Hiç doğada bulundun mu? Neresiydi?

4. Doğada olmak hoşuna gider mi? Neden?

Araştırmanın geçerliğini sağlamak için çocuklara yöneltilecek sorular hedef kitlenin gelişimsel özellikleri dikkate alınarak hazırlanmış ve uzman görüşüne sunularak onaylanmıştır. Ayrıca bulguların sunumunda çocukların çizdiği resimlere ve ifadelerinden doğrudan alıntılara yer verilmiştir. Güvenirliği sağlamak için ise iki uzman tarafından teyit amaçlı inceleme yapılmıştır. İnceleme sonucunda araştırma verileri, bulgular ve yorumlar arasındaki ilişkilerin tutarlılığı ve uyumuna ilişkin onay alınmıştır.

Görüşme verileri ve çocukların çizdikleri resimler, nitel veri analiz yöntemlerinden içerik analizi kullanılarak çözümlenmiştir. İçerik analizinde temelde yapılan işlem, birbirine benzer verileri, belirli kavramlar ve temalar çerçevesinde bir araya getirmek ve okuyucunun anlayacağı şekilde düzenleyerek yorumlamaktır (Yıldırım ve Şimşek, 2008). İçerik analizinde öncelikli olarak elde edilen veriler kodlama işlemine tabi tutulmaktadır. Bu süreçte Strauss ve Corbin (1990) tarafından belirtilen kodlama türlerinden tümevarımcı bir analiz ile verilerden çıkarılan kavramlara göre kodlama süreci gerçekleştirilmiştir (Akt. Yıldırım ve Şimşek, 2008). Analiz aşamasında öncelikle her çocuğa ait görüşme tutanakları ve resimler sıralamaya tabi tutulmuştur. Çizilen doğa resimleri çocuklara anlattırılmış ve çocukların ifadeleri kayıt altına alınmıştır. Çocukların çizdikleri resimler hakkındaki ifadeleri ve görüşmelerde açık uçlu sorulara verdikleri yanıtlar analiz edilerek kodlanmış, ortaya çıkan anlam doğrultusunda tema ve kategoriler belirlenmiştir. Kodlanan veriler, temalar ve kategoriler halinde tablolaştırılarak frekans ve yüzde olarak sunulmuştur. Çalışmada verilerin analizi iki araştırmacı tarafindan yapılmış ve karşılaştırılarak kontrol edilmiştir. Çocukların resimlerinde ve ifadelerinde birden fazla unsura yer verildiğinden bulguların sunumunda frekans sayısı katılımcı sayısını aşmıştır. İfadelerin ve resimlerin sunumunda çocuklar için belirlenmiş kısaltma ve sıra sayısını belirten kodlamalar (Ç1, Ç2...) kullanılmıştır.

\section{BULGULAR}

\section{Tablo 1.}

Çocuk Resimlerinde Doğa Algısı

\begin{tabular}{|c|c|c|c|}
\hline Tema & Kategori & f & İfadeler \\
\hline \multirow{3}{*}{ Canlı Unsurlar } & Bitkisel Unsurlar & 182 & $\begin{array}{l}\text { Ağaç }(\mathrm{f}=77) \text {; Çimen }(\mathrm{f}=57) \\
\text { Çiçek }(\mathrm{f}=47) ; \text { Tohum }(\mathrm{f}=1)\end{array}$ \\
\hline & Hayvanlar & 71 & $\begin{array}{l}\text { Kelebek }(\mathrm{f}=16) ; \operatorname{Kuş}(\mathrm{f}=16) ; \\
\text { Tavşan }(\mathrm{f}=10) \text {; At }(\mathrm{f}=5) ; \operatorname{Kaplumbağa~}(\mathrm{f}=4) ; \\
\text { Zürafa }(\mathrm{f}=3) ; \operatorname{Aslan}(\mathrm{f}=2) ; \text { Y1lan }(\mathrm{f}=2) ; \\
\text { Koyun }(\mathrm{f}=2) ; \operatorname{Salyangoz}(\mathrm{f}=2) ; \operatorname{Köpek}(\mathrm{f}=2) ; \\
\text { Kedi }(\mathrm{f}=1) ; \operatorname{Zebra}(\mathrm{f}=1) ; \operatorname{Kurt}(\mathrm{f}=1) ; \\
\text { Kaplan }(\mathrm{f}=1) ; \operatorname{Karga}(\mathrm{f}=1) ; \operatorname{Ay1}(\mathrm{f}=1) ; \\
\text { Uğurböceği }(\mathrm{f}=1)\end{array}$ \\
\hline & İnsan & 46 & $\begin{array}{l}\text { İnsan }(\mathrm{f}=23) \text {; Çocuk }(\mathrm{f}=22) \text {; } \\
\text { Gülen yüz }(\mathrm{f}=1)\end{array}$ \\
\hline
\end{tabular}


Tablo 1. devamı

Çocuk Resimlerinde Doğa Algısı

Tema Kategori

f

Ifadeler

Doğal unsurlar

\section{Cansız Unsurlar}

Beşeri unsurlar
Güneş ( $\mathrm{f}=72)$; Bulut $(\mathrm{f}=66)$; Yağmur $(\mathrm{f}=25)$;

Gökkuşağ1 (f=22); Toprak (f=15); Gökyüzü (f=12);

255 Deniz (f=7); Dă̆ (f=6); Şimşek (f=6); Ay ( $\mathrm{f}=6)$;

Akarsu (f=6); Y1ldız (f=4); Göl (f=3); Kaya (f=3);

Ateş $(\mathrm{f}=1)$; $\operatorname{Kar}(\mathrm{f}=1)$

Ev $(\mathrm{f}=26) ; *$ Nesneler $(\mathrm{f}=7) ;$ *Ulaşım araçları $(\mathrm{f}=6)$;

$68 \operatorname{Havuz}(\mathrm{f}=5)$; *Yapilar $(\mathrm{f}=5) ;$ * Oyuncak $(\mathrm{f}=4)$;

Bayrak ( $\mathrm{f}=4)$; Pasta $(\mathrm{f}=3)$; Dondurma $(\mathrm{f}=2)$;

Bahçe ( $\mathrm{f}=2)$; Merdiven ( $\mathrm{f}=2)$; Çadır $(\mathrm{f}=2)$

Not: *Frekansı iki ve altında olan bazı ifadeler tabloda gruplandırılarak kodlamalar şeklinde belirtilmiştir. Nesneler: Sandalye ( $f=1)$, Duvar saati $(f=1)$, Şemsiye $(f=1)$, Balta $(f=1)$, El feneri $(f=1)$, Mum $(f=1)$, Bardak (1); Ulaşım araçları: Araba ( $\mathrm{f}=2)$, Uçak $(\mathrm{f}=2)$, Helikopter $(\mathrm{f}=1)$, Otobüs $(\mathrm{f}=1)$; Yapılar: Okul $(\mathrm{f}=1)$, Otel $(\mathrm{f}=1)$, Depo $(\mathrm{f}=1)$, Karate salonu $(\mathrm{f}=1)$, Laboratuvar ( $\mathrm{f}=1)$; Oyuncak: Balon $(\mathrm{f}=2)$, Uçurtma ( $\mathrm{f}=1)$, Oyuncak silah $(\mathrm{f}=1)$.

Tablo 1'de görüldüğü üzere çocuklar resimlerinde en fazla cansız unsurlara yer vermişlerdir. Buna karşın kategoriler bağlamında bir değerlendirme yapıldığında cansız doğal unsurlar ve bitkisel unsurlar'in resimlerde ağırlıklı olarak yer aldığı tespit edilmiştir. Ağaç $(\mathrm{f}=77)$, güneş $(\mathrm{f}=72)$, bulut $(\mathrm{f}=66)$, çimen $(\mathrm{f}=57)$ ve çiçek $(\mathrm{f}=47)$ en fazla resmedilen unsurlar olmuştur. Cansız doğal unsurlar ve bitkisel unsurlardan sonra hayvanlar resimlerde sıklıkla ( $\mathrm{f}=71)$ ifade edilen diğer bir kategoriyi oluşturmaktadır. Resimlerde en düşük frekansa sahip kategoriyi ise insan ( $\mathrm{f}=46$ ) oluşturmaktadır. Çocukların çizdiği insan resmi sayısı canlı unsurlar içinde en düşük orana sahiptir. Benzer şekilde beşeri unsurlar da $(\mathrm{f}=68)$ doğal unsurlara göre daha düşük frekans değerine sahiptir.

Çocukların çizdiği doğa resmine örnekler Şekil 1, 2, 3 ve 4’te sunulmuştur:

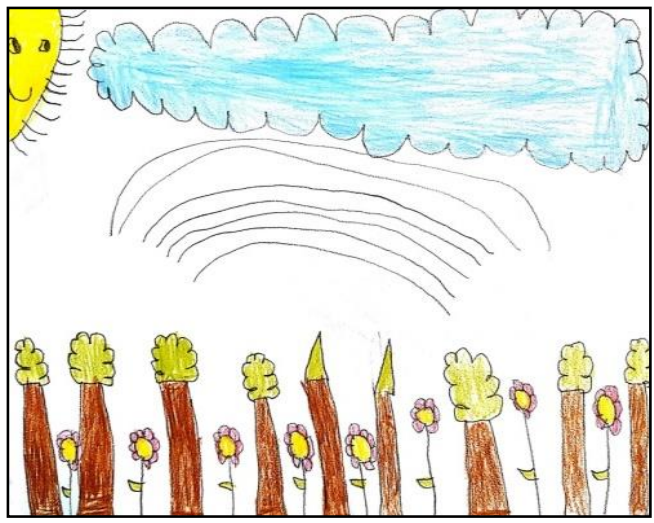

Şekil 1. Ç41'e ait doğa resmi

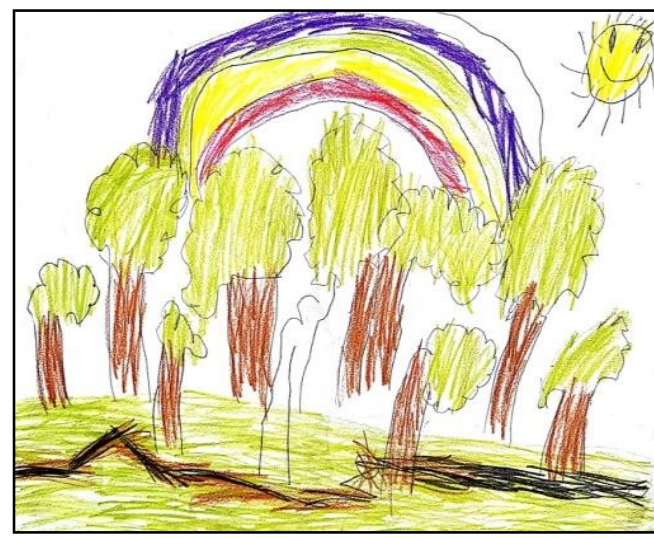

Şekil 3. Ç48'e ait doğa resmi

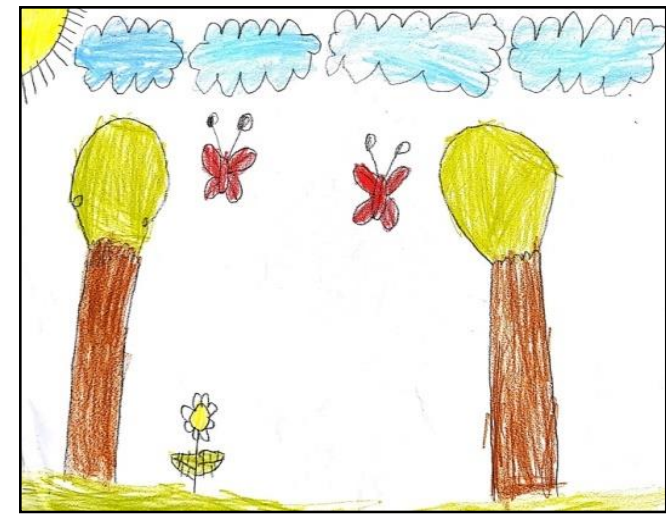

Şekil 2. Ç60'a ait doğa resmi

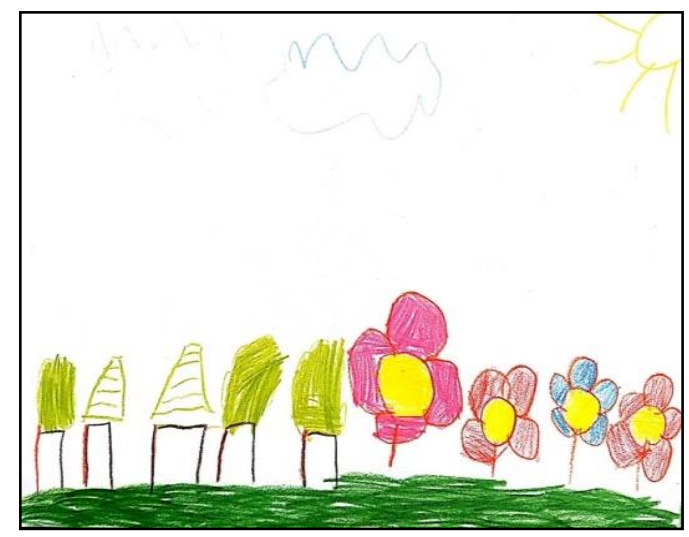

Şekil 4. Ç85'e ait doğa resmi 
Resim örneklerinde (Şekil 1-4) görüldüğü üzere doğa, çocuklar tarafindan ağırlıklı olarak bitkisel ve cansız doğal unsurlar üzerinden resmedilmiștir. Bununla birlikte bu unsurlara, hayvanlar, insan ve beşeri unsurların eşlik ettiği çizimler de bulunmaktadır (Şekil 5-10).

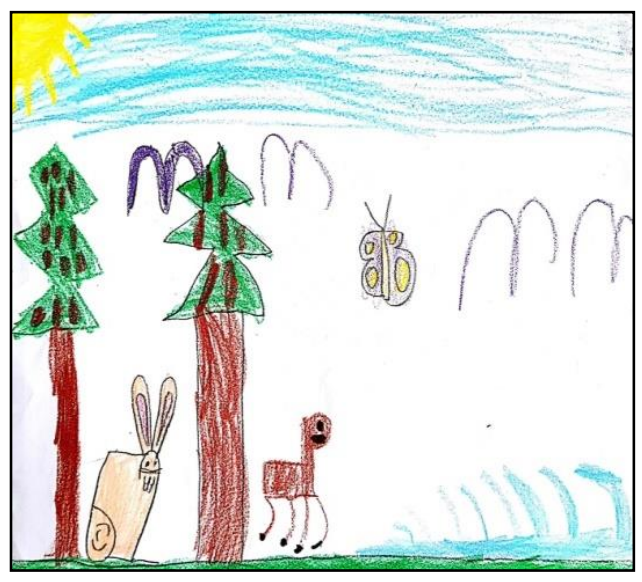

Şekil 5. Ç5'e ait doğa resmi

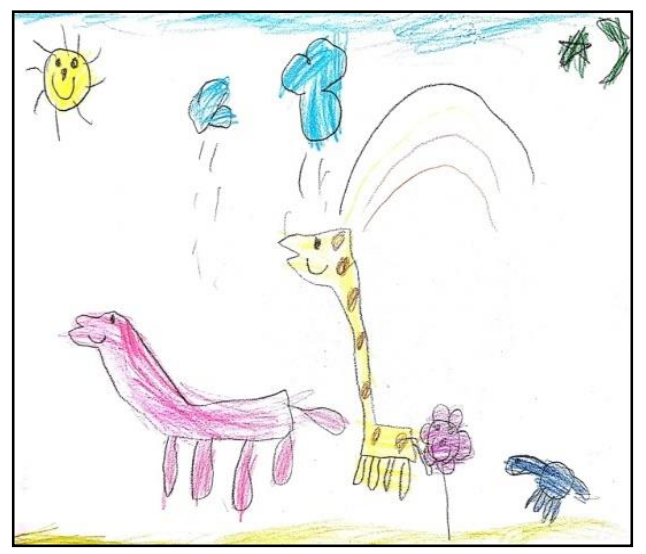

Şekil 7. Ç40'a ait doğa resmi

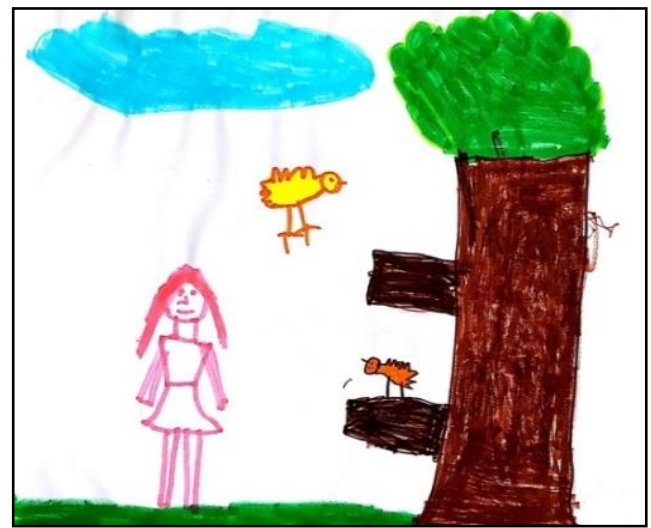

Sekil 9. Ç35'e ait doğa resmi

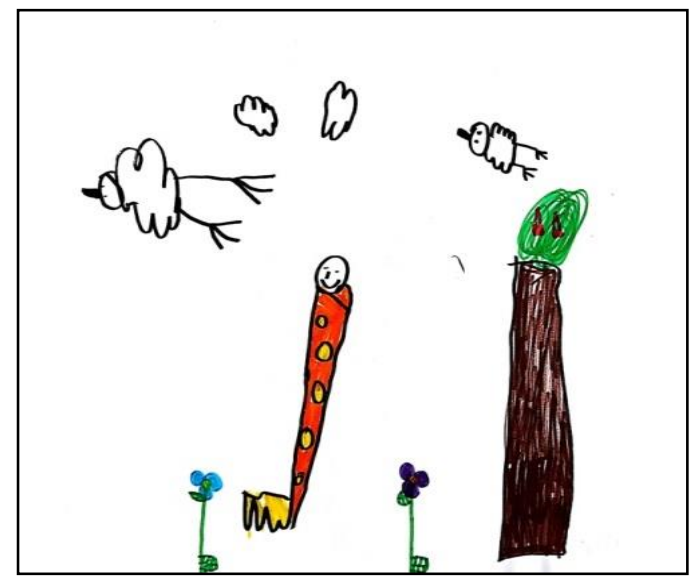

Şekil 6. Ç30'a ait doğa resmi

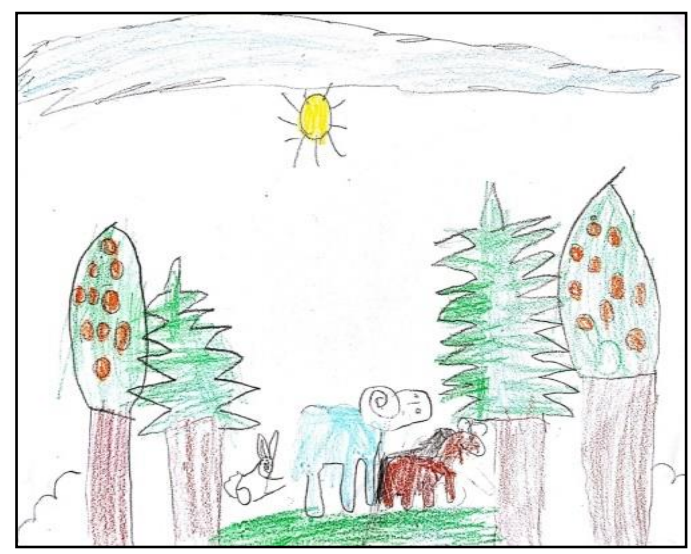

Şekil 8. Ç3'e ait doğa resmi

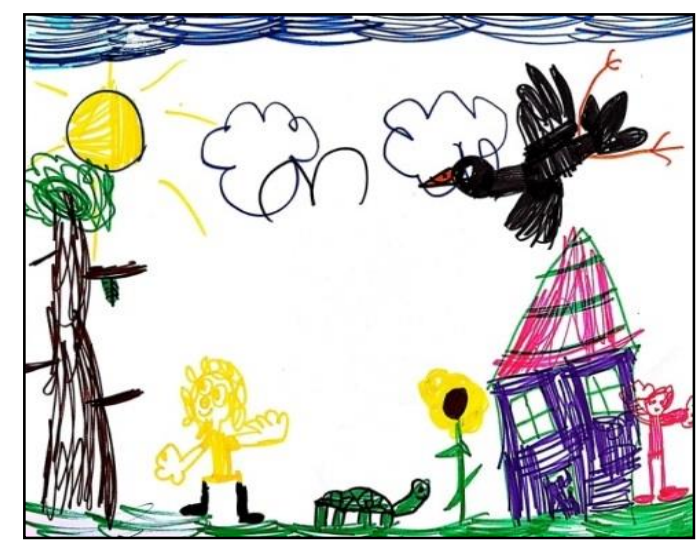

Şekil 10. Ç67'ye ait doğa resmi

Resimlerde görüldüğü üzere (Şekil 5-10), çeşitli hayvan türleri, beşeri unsurlar, bitkisel unsurlar ve insan, çocukların doğa algısını yansıtan resimlerde ifade edilmişlerdir. 
Tablo 2.

Çocukların Doğa Tanımlamaları

\begin{tabular}{|c|c|c|c|}
\hline Tema & Kategori & f & İfadeler \\
\hline \multirow{3}{*}{ Canlı Unsurlar } & Bitkisel Unsurlar & 70 & $\begin{array}{l}\text { Ağaç }(\mathrm{f}=25) \text {; Orman }(\mathrm{f}=23) \text {; Çiçek }(\mathrm{f}=15) \text {; } \\
\text { Çimen }(\mathrm{f}=3) \text {; Yeşil }(\mathrm{f}=3) \text {; Bitki }(\mathrm{f}=1)\end{array}$ \\
\hline & Hayvanlar & 74 & 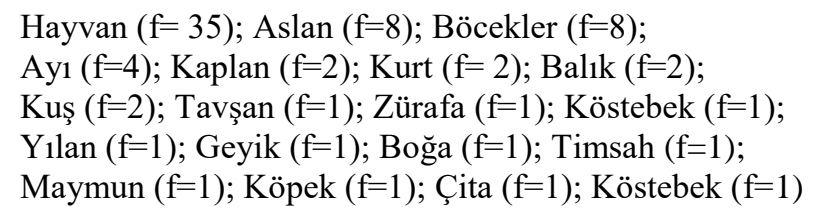 \\
\hline & İnsan & 2 & İnsan $(\mathrm{f}=2)$ \\
\hline \multirow{2}{*}{ Cansız Unsurlar } & Doğal unsurlar & 11 & $\begin{array}{l}\text { Yağmur (f=4); Akarsu (f=2); Gökyüzü }(\mathrm{f}=1) \text {; Deniz }(\mathrm{f}=1) \text {; } \\
\text { Toprak (f=1); Güneş }(\mathrm{f}=1) \text {; Gökkuşağı }(\mathrm{f}=1)\end{array}$ \\
\hline & Beşeri unsurlar & 7 & $\begin{array}{l}\text { Bahçe }(\mathrm{f}=2) ; \text { Köprü }(\mathrm{f}=1) \text {; Salıncak }(\mathrm{f}=1) ; \\
\text { Araba }(\mathrm{f}=1) ; \text { Yol }(\mathrm{f}=1) ; \text { Okul }(\mathrm{f}=1)\end{array}$ \\
\hline \multirow{3}{*}{$\begin{array}{l}\text { Duygu ve } \\
\text { Estetik }\end{array}$} & Estetik & 5 & Koku (f=3); Güzel (f=1); Aydınlık (f=1) \\
\hline & Yaşam kaynağı & 5 & Yaşam kaynağı $(\mathrm{f}=5)$ \\
\hline & Duygu & 2 & Sevgi doludur $(f=1)$; Sevdiğimiz yer $(f=1)$ \\
\hline Betimleme & Mekân & 5 & $\begin{array}{l}\text { Kocaman/büyük bir yer }(f=2) \text {, } \\
\text { Piknik yeri }(f=2) \text {; Gezilecek yer }(f=1)\end{array}$ \\
\hline
\end{tabular}

Tablo 2’de görüldüğü üzere çocukların doğa tanımlamalarına ilişkin analiz sonuçları değerlendirildiğinde, çocukların doğayı en fazla hayvanlar ve bitkisel unsurlar üzerinden tanımladıkları görülmektedir. Doğa tanımlamalarında hayvanları ifade eden çocukların ağırlıklı olarak vahşi hayvanlara işaret ettiği dikkati çekmektedir. Doğa'yı hayvanların yaşadığı yer olarak tanımlayan çocukların ifadelerine örnekler aşağıda verilmiştir:
Ç30: Doğa hayvanların evidir.
Ç54: Hayvanların olduğu yer. Aslan, geyik, boğa, timsah, balı̆̆ının olduğu yerdir.
Ç87: Hayvanların yaşadı̆̆ yerdir. Kaplan, aslan, çita gibi çok hayvan var.
Ç93: Doğa hayvanların yaşadı̆̆ yerdir.
Ç98: Kelebeklerin, çiçeklerin, özgür hayvanların, çekirgelerin yaşadı̆̆ı yerdir.

Örneklerden de görüldüğü üzere çocuklar için doğa, vahşi ya da başka bir ifadeyle özgür hayvanların yaşadığı bir mekân olarak tanımlanmaktadır.

Çocukların doğa tanımlamalarında öne çıkan bir diğer kategori ise bitkisel unsurlar olmuştur. Bu kategori altında ăgaç ve orman olarak doğa tanımlamaları daha sık dile getirilmiştir. Orman ifadesi çocuklar tarafından bir ekosistem olarak değil "ağaçların fazla olduğu yer" anlamında kullanılmıştır. Çocukların ifadelerine örnekler aşağıda verilmiştir:

Ç5: Doğada çiçekler vardır. Papatyalar, güller, menekşeler vardır. Ăgaçlarla doludur.

Ç19: Ormanlık yere doğa denir. Yolların kenarında çok ă̆aç var. Ağaç olunca orası hep doğa oluyor.

Ç35: Doğa, ağaçların oldŭ̆u yemyeşil bir yerdir.

Ç63: Yeşillik içinde bir yer demek. Orada ă̆açlar olur ve piknik yapılır.

Ç85: Yemyeşil yerler, çiçekler, güneş, temiz kokular, insanlar.

Çocukların ifadeleri genel olarak değerlendirildiğinde doğa, bitkisel ve hayvansal unsurlardan oluşan bir bütün olarak tanımlanmıştır:

Ç7: Kocaman vahşi hayvanların olduğu, yağmur ormanı diye ormanların olduğu bir yerdir. Orada hep yă̆mur var. 
Ç42: Yă̆murlarla dolu yerdir. Orman gibidir, ağaçlarla, çiçeklerle doludur. Hep yağmur yağar, toprak altından köstebek çıkar, çimenler vardır.

Ç55: Ăgaçlar, çiçekler, orman ve hayvanların olduğu yerdir.

Ç81: Hayvanların olduğu yerdir. Çiçek, böcek ve ă̆aç vardır.

Ç83: Ormandır. Hayvanlar yaşar. Uğur böcekleri, arılar, sinekler, ayılar yaşar. Yaşamdır.

Doğa tanımlamalarında "insan" unsurunun sadece 2 çocuk tarafından dile getirildiği dikkat çekmektedir.

Ç17: Bizim sevdiğimiz bir yerdir. Orada sevdiğimiz şeyler var. Doğada insan da vardir.

Ç85: Yemyeşil bir yer, çiçekler, güneş, temiz koku, insanlar var.

Çocukların doğa tanımlamalarında insan unsuruna yeterince yer vermemiş olmaları, insanı doğanın dışında değerlendiren bir anlayışa sahip olduklarını göstermektedir.

Tablo 3.

Çocuklara Göre Doğadaki Unsurlar

$\begin{array}{llll}\text { Tema } & \text { Kategori } & \text { I } & \text { Ifadeler }\end{array}$

Bitkisel Unsurlar

150

Canlı Unsurlar Hayvanlar

260

İnsan

Doğal unsurlar

87

\section{Cansiz Unsurlar}

Beşeri unsurlar
Ağaç ( $\mathrm{f}=66)$; Çiçek ( $\mathrm{f}=47)$; Çimen ( $\mathrm{f}=25)$; Orman $(\mathrm{f}=4)$;

Gül ( $\mathrm{f}=4)$; Papatya $(\mathrm{f}=3)$; Yeşillik $(\mathrm{f}=1)$

Hayvan ( $\mathrm{f}=33)$; Kuş ( $\mathrm{f}=19) ;$ Ayı ( $\mathrm{f}=15)$;

Aslan ( $\mathrm{f}=15)$; Kelebek ( $\mathrm{f}=13)$; Tavşan $(\mathrm{f}=13)$;

Kedi ( $\mathrm{f}=10)$; Kaplan ( $\mathrm{f}=10)$; Köpek $(\mathrm{f}=9)$;

Kurt (f=8); Kaplumbağa (f=7); Arı (f=7);

At $(\mathrm{f}=7)$; Maymun $(\mathrm{f}=6)$; İnek $(\mathrm{f}=6)$;

Zürafa $(\mathrm{f}=6)$; Böcek ( $\mathrm{f}=6)$; Sincap $(\mathrm{f}=5)$;

Fil $(\mathrm{f}=4) ;{ }^{*}$ Diğer hayvanlar $(\mathrm{f}=61)$

24 İnsan (f=17); Cocuk (f=4); Aile ( $\mathrm{f}=1)$;

$\mathrm{K} 1 \mathrm{z}(\mathrm{f}=1)$; Adam ( $\mathrm{f}=1)$

Bulut ( $\mathrm{f}=22)$; Güneș ( $\mathrm{f}=19)$; Gökkuşağı $(\mathrm{f}=9)$;

Yağmur (f=6); Toprak (f=5); $\mathrm{Su}(\mathrm{f}=5)$;

Deniz ( $\mathrm{f}=4)$; Şelale ( $\mathrm{f}=4)$; Göl ( $\mathrm{f}=2)$;

Bataklık ( $\mathrm{f}=2) ; \operatorname{Ay}(\mathrm{f}=2) ;$ Taş $(\mathrm{f}=2) ; \operatorname{Kum}(\mathrm{f}=1)$;

Şimşek ( $\mathrm{f}=1)$; Okyanus $(\mathrm{f}=1)$; Nehir $(\mathrm{f}=1)$; Mağara $(\mathrm{f}=1)$

Ev (f=9); Piknik Alanı ( $\mathrm{f}=3$ ), Oyuncak $(\mathrm{f}=2)$,

Kamp ( $\mathrm{f}=2)$, Bahçe ( $\mathrm{f}=2)$; Okul ( $\mathrm{f}=2)$;

Çadır ( $\mathrm{f}=1)$; Uçak ( $\mathrm{f}=1)$; Helikopter ( $\mathrm{f}=1)$;

$32 \operatorname{Havuz}(\mathrm{f}=1)$; Uçurtma ( $\mathrm{f}=1)$; Mangal $(\mathrm{f}=1)$;

Kulübe (f=1); Yol ( $\mathrm{f}=1)$; Gölet ( $\mathrm{f}=1)$;

Masa (f=1); Sandalye ( $\mathrm{f}=1)$; Araba $(\mathrm{f}=1)$

Not: *Frekans değeri üç ve altında olan diğer hayvanlar: Koyun (f=3), Zebra (f=3), Köpekbalığı (f=3), Balık (f=3), Geyik $(\mathrm{f}=3)$, Çita $(\mathrm{f}=3)$, Deve ( $\mathrm{f}=3$ ), Baykuş $(\mathrm{f}=2)$, Şahin $(\mathrm{f}=2)$, Karga ( $\mathrm{f}=2)$, Civciv $(\mathrm{f}=2)$, Tilki $(\mathrm{f}=2)$, Solucan ( $\mathrm{f}=2)$, Kuzu ( $\mathrm{f}=2)$, Uğurböceği ( $\mathrm{f}=2)$, Leylek $(\mathrm{f}=1)$, Papağan $(\mathrm{f}=1)$, Yarasa $(\mathrm{f}=1)$, Ördek $(\mathrm{f}=1)$, Jaguar $(\mathrm{f}=1)$, Leopar $(\mathrm{f}=1)$, Salyangoz $(\mathrm{f}=1)$, Kertenkele ( $\mathrm{f}=1)$, Horoz $(\mathrm{f}=1)$, Tavuk $(\mathrm{f}=1)$, Güvercin $(\mathrm{f}=1)$, Yunus $(\mathrm{f}=1)$, Balina $(\mathrm{f}=1)$, Yengeç $(\mathrm{f}=1)$, Koala $(\mathrm{f}=1)$, Köstebek $(\mathrm{f}=1)$, Akrep ( $\mathrm{f}=1)$, Timsah ( $\mathrm{f}=1)$, Örümcek $(\mathrm{f}=1)$, Çekirge ( $\mathrm{f}=1)$, Eşek ( $\mathrm{f}=1)$, Kurbağa $(\mathrm{f}=1)$, Gergedan ( $\mathrm{f}=1)$, Su aygirı ( $\mathrm{f}=1)$.

Çocukların “doğada neler var?” sorusuna verdikleri yanıtlar analiz edildiğinde elde edilen bulgular doğrultusunda Canlı unsurlar temasının ( $(=434)$ en yüksek frekansa sahip olduğu görülmektedir $($ Tablo 3$)$. Bu tema altında hayvanlar ve bitkisel unsurlar kategorilerinin frekans değerleri daha yüksektir. Doğa tanımlamalarında olduğu gibi hayvanlar sıklıkla belirtilen unsur olmuştur. Hayvan türlerini belirten çocukların \%39,2'si (f= 102) ağırlıklı olarak çevrelerinde göremeyecekleri yabani hayvanları (akrep, aslan, ayı, balina, baykuş, çita, deve, fill, gergedan, geyik, jaguar, kaplan, koala, köpekbalığı, kurt, leopar, maymun, papağan, zürafa, sincap, su aygırı, şahin, tilki, timsah, yarasa, yengeç, yunus, zebra) dile getirmişlerdir. Bitkisel unsurlardan ağaç ( $\mathrm{f}=66)$ ve çiçek $(\mathrm{f}=47)$, bu soruya verilen yanıtlar içinde en yüksek frekans değerine sahip unsurlardandır. Canlı unsurlar teması altında insan kategorisi en az frekans değerine sahiptir. Cansız unsurlar teması altında ise doğal unsurlar kategorisi, frekans değerleri bakımından bitkisel unsurlar ve hayvanlar kategorisini takip etmektedir. 
Çocukların ifadelerine örnekler aşağıda verilmiştir:

Ç9: Çiçekler, evler, bulutlar, güneş, gökkuşă̆l ve çocuklar var.

Ç18: Doğada bulut, balık, çocuklar vardır.

Ç41: Doğada çiçekler ve ă̆açlar var. Bir de koyun, inek, aslan, kaplan olur.

Ç65: Kaplumbağa, kuş, çimen, ă̆aç ve böcekler var. Bunlarl çizgi filmde gördüm.

Ç73: Tavşan, kedi, aslan, kaplan, kurt, zebra, çiçek, çimen olur. Bazen doğada insanlar da oluyor. Orada ateş yakıyorlar

Çocukların “doğada neler var?” sorusuna teker teker unsurları sayarak yanıt verdikleri dikkati çekmektedir. Dolayısıyla daha çok doğadaki nesnelere odaklanan bir doğa anlayışına sahip oldukları söylenebilir. Nesnelere odaklanmış çocukların ifadelerine örnekler şu şekildedir:

Ç7: Çiçekler, ağaçlar, kelebekler, arllar, vahşi hayvan (ayl, aslan, kaplan, çita, şahin) var.

Ç14: Hayvanlar, arllar, ayı, aslan, ăgaçlar, güneş, bulutlar var. Uçak, helikopter doğadan geçer.

Doğada deniz de vardır.

Ç19: Ăgaç, hayvanlar (maymun, baykuş, kuşlar, tavşan, kurt) var. Doğada köpek yok kurt var. Ayl da var. Çiçekler, papatya, gül var. Doğaya piknik yapmaya gidilir.

Ç52: Hayvan, kuş, köpek, kurt, arı, kaplan, aslan, çita, kedi, ăgaçlar, gökkuşă̆l ve yağmur var.

Ç73: Tavşan, kedi, aslan, kaplan, kurt, zebra, çiçek, çimen var. Bazen doğada insanlar da oluyor.

Çalışmaya katılan çocukların \%97'si nesnelere odaklanmış doğa bir anlayışına sahipken sadece \%3'ü doğadaki ilişkilere yönelik farkındalık sahibidir. Doğadaki unsurlar ve bu unsurlar arasındaki ilişkiyi ifade eden çocukların ifadeleri şu şekildedir:

Ç20: Çiçek, ă̆aç, güneş, bulut, ayl, aslan, kaplan, kaplumbă̆a, zürafa var. Ormanda ă̆aç kesenler var. Odun yapmak için. Ama ă̆aç olmazsa toprak kayar. Ăgaç kesilirse toprak kayar. Ağaçlar toprakları tutuyor. Ağaçlar bazı hayvanların karnını doyuruyor. Zürafalar oradan yaprak yiyor. Kuşlar oraya yuva yapıyor.

Ç83: Şelale, gergedan, fil, kertenkele, at, su aygırı, sincap, ă̆açlar var. Sincaplar ăgaçların üstünde olur. Şelaleden filler su içer. Tavuk belki olur. Çocuklar da hayvanları sevmeye gelir.

Ç88: Ăgaçlar, böcekler, kuşlar, hayvanlar var. Dünya bizim nefes almamız için, ăgaçlar bizim sağlıklı olmamız içindir. Ağaçlar olmasa biz nefes alamayız. Doğada hayvanlar yaşar, insanlar yaşar. Cıvıldayan leylekler, güvercinler vardır.

Tablo 4.

Çocukların Doğa Deneyimleri

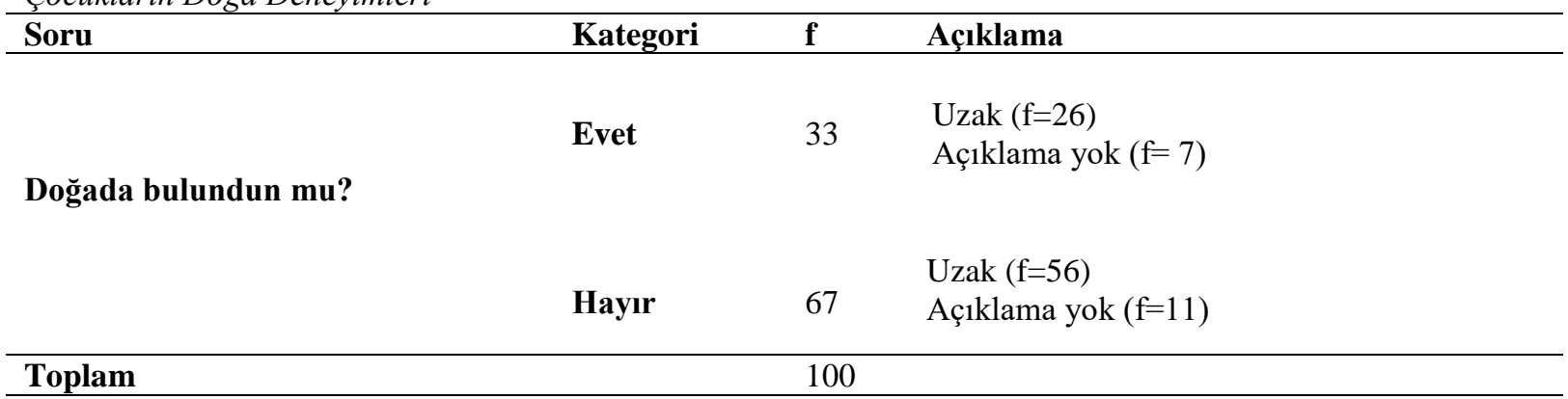

Evet

Doğada olmak hoşuna gider mi?
Hayvanlar ( $\mathrm{f}=32)$; Bitkiler $(\mathrm{f}=31)$;

Güzel (f=8); Oyun yeri ( $\mathrm{f}=6)$;

Piknik yeri $(\mathrm{f}=5)$; Kamp yeri $(\mathrm{f}=4)$;

Tatil yeri $(\mathrm{f}=2)$; $\mathrm{Su}(\mathrm{f}=3)$; Temiz hava $(\mathrm{f}=1)$;

Bilmiyorum ( $\mathrm{f}=2)$; Açıklama yok $(\mathrm{f}=12)$

\footnotetext{
Hayır

Toplam

11 Vahşi hayvanlar ( $\mathrm{f}=11)$ 100

Tablo 4’te görüldüğü üzere çocukların \%67'si daha önce doğada bulunmadığını belirtmiştir. Daha önce doğada bulunmadığını belirten çocukların \%83,5'i bu duruma doğanın "uzakta” bir yerlerde olmasını sebep olarak göstermişlerdir. Ancak benzer şekilde daha önce doğada bulunduğunu belirten çocuklar için de $(\% 78,7)$ doğa "uzakta" bir yerdedir. Dolayısıyla araştırmaya katılan çocukların \%82'si için doğa yaşadıkları yerden uzakta bulunan bir ortamdir.
} 
Çocukların \%89'u doğada bulunmaktan hoşlanacağını belirtmişlerdir. Bunun sebebini ise ağırlıklı olarak doğada bulunan hayvanlar $(\% 35,9)$ ve bitkisel unsurlar $(\% 34,8)$ olarak belirtmişlerdir. Ancak bazı çocuklar için hayvanlar doğada bulunmaktan korkma nedenini de oluşturmaktadır. Çalışmaya katılan çocukların \%11'i doğada bulunmak istemediklerini belirtmiş̧ler ve bunun nedenini vahşi hayvanlara karşı duydukları korku olarak ifade etmişledir. Doğada bulunmaktan hoşlanacağını belirten çocukların \%13,4'ü bu duruma herhangi bir açıklama getiremezken; \%19,1'i için ise doğa daha çok eğlenme (oyun, piknik, kamp, tatil) yeridir

\section{TARTIŞMA ve SONUÇ}

$\mathrm{Bu}$ çalışma, okul öncesi yaş grubunda bulunan çocukların doğa algılarını belirlemek amacıyla gerçekleştirilmiştir. Çalışmada, çocukların resimlerinde cansız unsurlara sıklıkla yer verdikleri tespit edilmiştir. Güneş ve bulut en fazla resmedilen cansız doğal unsurlar olarak dikkati çekmektedir. Canlı unsurlar teması altında ise ağaç, çimen ve çiçek en fazla resmedilen unsurlar olmuştur. Çocuk resimlerinde evler, hayvanlar ve ağaç sık rastlanılan çizimlerdendir (Yavuzer, 2009). Çocuklar genel olarak ev, bitki ve hayvan betimlemelerini resimlerinde sıklıkla tercih etmektedirler (Kellog'dan Akt. Artut, 2004). Dolayısıyla bu durum doğaya ilişkin bir farkındalığın belirtisi olarak tek başına değerlendirilmeyebilir. Buna rağmen beşeri unsurlara sıklıkla yer verilmemesi $(f=68)$, doğaya ve doğal unsurlara karşı geliştirilen farkındalığın resimlere yansıtıldığı şeklinde yorumlanabilir. Çocukların doğaya ilişkin tanımlamaları da, bu farkındalığa sahip olduklarını göstermektedir. Doğa tanımlamalarına ilişkin sonuçlar, çocukların doğayı en fazla hayvanlar ve bitkisel unsurlar üzerinden tanımladıklarını göstermektedir. Ayrıca çocuklara göre doğada bulunan unsurlar içinde ağaç $(\mathrm{f}=66)$ ve çiçek $(\mathrm{f}=47)$ yüksek frekans değerine sahiptir. Keliher $(1997$, s. 241) tarafından yapılan araştırmada 6-7 yaşındaki çocukların doğayı ağaçlar, çiçekler ve hayvanlar olarak algıladıkları belirlenmiştir. Aile geçmişleri ve açık hava deneyimleri ne olursa olsun bütün çocukların kuş ve ağaçtan bahsettikleri, bütün çocukların resimlerinde mutlaka ağaç olduğu tespit edilmiştir.

Çocuklarla gerçekleştirilen görüşmeler sırasında sıklıkla öne çıkan kategori ise hayvanlar olmuştur. Çocukların, resimlerinde hayvanlara, bitkisel unsurlar ve cansız doğal unsurlar kadar sıklıkla yer vermedikleri ancak görüşmeler esnasında hayvanları sıklıkla vurguladıkları dikkat çekmektedir. Hayvanlar kategorisi toplam olarak hem doğa tanımlamalarında hem de doğadaki unsurlar içinde en yüksek frekansa sahiptir. Çocukların doğada bulunduğunu ifade ettikleri hayvanların \%39,2'si ( $\mathrm{f}=102)$ ise çevrelerinde göremeyecekleri yabani türlerden oluşmaktadır. Strommen (1995) tarafından birinci sınıfa giden çocuklarla orman hakkında resim çizimi ve görüşmeler yapılmış, çocukların ormanları, orman sakinlerine (örneğin geyik ve sincaplara) tahsis etmiş olmalarına rağmen, hemen hemen tüm diğer hayvanlara (filler, köpekbalıkları, vb.) ve özellikle etçillere de yer verdikleri belirlenmiştir. Doğanın çocuklar tarafından hayvanlar üzerinden algılanmasının, özellikle okulöncesi dönemde okutulan hikâye kitapları ile ilgili olduğu düşünülebilir. Gönen ve diğerleri (2013) tarafindan okulöncesi dönemi çocuk kitaplarının incelendiği çalışmada, \%60'ının öykü olduğu görülen kitapların \%52'si hayvan öyküsünden oluşmaktadır. Ayrıca incelenen resimli çocuk kitaplarının karakter özellikleri bakımından \%52'sinin hayvan karakterlerden oluştuğu tespit edilmiştir. Şahin, Işıtan ve Ünal'ın (2012) çalışmasında üç-altı yaş resimli çocuk kitaplarında en çok hayvan karakterlere yer verildiği görülmüştür. Yerli kitaplarda hayvan karakterler \%53,4, çeviri kitaplarda \%71,4 oranında birinci karakter olarak belirlenmiştir. Kitaplarda ikinci ve üçüncü karakter olarak ta en fazla hayvanlar yer almaktadır. Yılmaz-Genç ve Özen-Uyar'ın (2016) çalışmasında ise resimli çocuk kitaplarında kullanılan karakter dağılımlarına ait bulgulara göre \%41,1 oranında hayvan karakterine, $\% 36,6$ oranında insan karakterine ve $\% 8,9$ oranında doğal varlıklara yer verildiği belirlenmiştir. Dolayısıyla, çocukların doğa algılarının çevrelerinde göremeyecekleri hayvanlar üzerinden şekillenmesinde okulöncesi yaş grubuna yönelik kitaplarda hayvanların karakter olarak kullanılmasının etkili olduğu söylenebilir. $\mathrm{Bu}$ durum ise okul dışı doğa etkinliklerinin yetersizliği ve sınıf içindeki etkinlikler yoluyla bir doğa algısı oluşturulduğu şeklinde değerlendirilebilir.

Çalışmada çocukların \%97'si nesnelere odaklı bir doğa anlayışına sahiptir. Benzer şekilde Taşkın ve Şahin'in (2008) çalışmasında da çocuklar; çevrelerinde ağaç, çocuk, çiçek, kuş vb. gibi nesneleri gördüklerini söylemekte ve bunları resmetmekte ancak bu nesnelerin birbirleri arasındaki ilişkileri ifade edememektedirler. Bu durum çocukların yaş gruplarının bir özelliği olarak algılama düzeylerinden kaynaklı olabilir. Ancak çok daha basit düzeyde dahi ilişkilerin (örneğin bitki, toprak, hayvan, insan ilişkisi temelinde) ifade edilmemesi, algılama düzeylerini zenginleştirecek gözlemler ya da deneyimlerin eksikliğine de işaret etmektedir. Ülkemizde doğa ile ilgili projeler, doğayı parçalar halinde ele alan ve doğa bilincinin daha çok örgün eğitim yoluyla geliştirilebileceği bir anlayış çerçevesinde oluşturulmaktadır. Bu anlayış, parçacı yaklaşımı ve uygulamayı sınırlı ölçüde içerdiğinden, doğa bilinci kazandırmada yeterli değildir (Çukur ve Özgüner, 2008). Türkiye'de okul öncesi eğitim programında (MEB, 2013) doğrudan doğa eğitimine ve bu bağlamda doğadaki ilişkiselliğin kavranmasına ilişkin bir kazanım bulunmamaktadır. Dolayısıyla nesne odaklı bakış açısı, özellikle sınıf içinde gerçekleştirilen doğa eğitimi anlayışının odağını oluşturmaktadır. Bu durumun sonucu olarak doğayı nesneler üzerinden değerlendirme anlayışı, çevreye ve doğaya karşı herhangi bir sorumluluk gerekliliğini ortadan kaldırmaktadır. İlişkisel bakış açısını kazanmış çocuklar ise çevreye karşı eylemlerini bütünleştirmeye eğilimli 
olacaklardır. Doğaya ilişkin bir eğitim sürecinin sınırlı, nesnelleştirilmiş görüşlerden çok daha geniş, ilişkisel görünümlere odaklanması bir gerekliliktir (Loughland, Reid ve Petocz, 2002). Okulöncesinden itibaren gerçekleştirilecek doğa eğitiminin, çocukların algısal becerilerini dikkate alacak disiplinler arası bir anlayışla, hem okul içi hem okul dışında gerçekleştirilecek ve doğadaki çeşitliliğii, ilişki düzenini kavratacak etkinlikleri içermesi bu anlamda önem taşımaktadır.

Çocuklar insan unsuruna, doğa tanımlamaları $(\mathrm{f}=2$ ) ve doğadaki unsurlara ( $\mathrm{f}=24)$ ilişkin ifadelerinde sıklıkla yer vermemişlerdir. Farklı öğretim kademelerinde gerçekleștirilen benzer çalışmalarda da insan unsurunun doğadan ya da doğal çevreden ayrı düşünüldüğüne ilişkin bulgular elde edilmiştir (Köşker, 2013; Yardımcı ve Kılıç, 2010). Phenice ve Griffore (2003) tarafindan yapılan araştırmada 32-72 aylık 123 çocuğa doğa hakkında sorular sorularak algıları değerlendirilmiştir. Bu çalışmada çocuklar sırayla ağaçları, hayvanları, bitkileri ve insanları doğanın bir parçası olarak algılamaktadırlar. Bu unsurlar içinde en az insan doğanın parçası olarak görülmektedir. Shepardson, Wee, Priddy ve Harbor (2007) tarafindan ilkokuldan liseye kadar çeşitli okullarda öğrenim gören katılımcılarla gerçekleştirilen çalışmada ise çevre kavramı sorgulanmış ve katılımcıların \%35'i "bitki ve hayvanların yaşadığı doğal ortam" olarak yanıt vermişlerdir. Dolayısıyla insanın doğadan uzakta, doğadan ayrı bir varlık olduğuna yönelik anlayış, küçük yaşlardan itibaren başlamakta, doğal ortam ve kültürel ortam birbirinden ayrı iki farklı yaşam alanı olarak düşünülmektedir.

Araştırmaya katılan çocukların \%82'si için doğa yaşadıkları yerden "uzakta" bulunan bir ortamdır. Daha önce doğada bulunmadığını belirten çocukların \%83,5'i ve doğada bulunduğunu belirten çocukların \%78,7'si doğanın "uzakta" bir yerlerde olduğunu belirtmişlerdir. Benzer şekilde Aaron ve Witt (2011) tarafindan yapılan araştırmada beşinci sınıf öğrencilerinin doğa algılarını, doğal elementler üzerinden açıkladıkları (ağaçlar, bitkiler, hayvanlar, vahşi... vb.); doğayı, şehir dışı, medeniyetin olmadığı, insan yapımı olmayan, açık hava olarak tanımladıkları belirlenmiştir. Öğrenciler doğa ile dışarı kavramını birbirinin yerine kullanmışlardır.

Çocukların \%89'u doğada olmaktan hoşlanacaklarını belirtirken \%11'i doğada bulunmak istemediklerini dile getirmişlerdir. Doğada bulunmak isteyen ve doğayı seven çocukların \%19,1'i için doğa, daha çok eğlenme deneyimi (Oyun, Piknik, Kamp, Tatil yeri ) ile ilişkilendirilmiştir. Çocukların \% 13,4'ü ise herhangi bir açıklama yapmamıştır. Bu durum çocukların doğa deneyimlerinin yetersiz ya da sınırlı olduğunu göstermektedir. Doğada bulunmak istemediklerini belirten çocuklar (\%11) ise, bu duruma sebep olarak vahşi hayvanlara karşı duydukları korkuyu belirtmişlerdir. Bazı araştırma sonuçları çocukların doğaya ya da hayvanlara karşı (Burgess ve Mayer-Smith, 2011) çeşitli korkulara sahip olduğunu göstermektedir. Doğal dünya ile etkileşimin sınırlı olması ve doğa deneyimlerinin yetersizliği, çocuklarda bilinmeyen durumlara karșı korku geliștirilmesine neden olabilmektedir. Bu bağlamda erken yaşlarda gerçekleştirilecek doğa deneyimleri, olumsuz algı ve korkularının azalmasında etkili olacaktır.

Erken çocukluk dönemi doğa sevgisi ve doğa bilincinin kazandırılacağı kritik bir dönemdir. Doğa ile ilgili deneyimler, çocukların farkındalık kazanmalarına, empati ve doğa sevgisi geliștirmelerine yardımcı olacaktır. Güler'in de (2009) ifade ettiği gibi doğanın anlamı onunla etkileşim halindeyken öğrenilebilir. Bu dönemde sınıf ve okul dışında gerçekleştirilecek doğa eğitimi etkinlikleri, çocukların doğayı ve doğadaki çeşitliliği bir bağlam içinde, ilişkiler temelinde algılamalarını; farkındalık ve doğa sevgisi geliştirebilmelerini sağlayacaktır. Bu nedenle sınıf ve okul dışı doğa etkinlikleri bilişsel, duyuşsal ve devinimsel alanda, okul öncesi eğitim programının içeriğine dâhil edilmelidir. Dolayısıyla çocuk için, uzaklarda bir yerlerde değil, tanıdı̆̆ı, anladığı, deneyimlediği, kendisini bir parçası olarak algılayacağı doğa, hem bir öğrenme hem de yaşam alanına dönüşecektir. Doğaya ilişkin yükseköğretim kurumlarından katılımcılarla gerçekleştirilen çalışmalara (Dervişoğlu ve Kılıç, 2013; Kahyaoğlu ve Kırıktaş, 2016; Köşker, 2013; Kutru ve Soran, 2012) göre doğa algıs1 (bitkilerin, hayvanların bulunduğu yaşam alanı, yeşil vb.), yükseköğretim kademelerinde de çok büyük farklılık ya da değişiklik göstermemektedir. Dolayısıyla okulöncesinden yükseköğretime kadar olan süreçte, bireylerin zihninde ya da yaşamında doğaya iliş̧in algılarını zenginleştirecek nitelikte bir eğitim sürecinin varlığından söz etmek mümkün görünmemektedir. Bu bağlamda, öğretim programlarının disiplinler arası bir bakış açısıyla doğa eğitimine yönelik, özellikle okul dışı etkinliklerle zenginleștirilmesi, bununla birlikte yükseköğretimde, özellikle eğitim fakültelerinde doğa eğitimi uygulamalarının yaygınlaştırılması, doğayı, doğadaki ilişkileri ve süreçleri tanıyan, anlayan ve bunların yaşam için önemini fark eden bireylerin eğitimi açısından önem taşımaktadır. 


\section{KAYNAKÇA}

Aaron, R. F., \& Witt, P. A. (2011). Urban students' definitions and perceptions of nature. Children Youth and Environments, 21(2), 145-167.

Akköse, E. E. (2008). Okulöncesi eğitimi fen etkinliklerinde doğa olaylarının neden sonuç ilişkilerini belirlemede yaratıcı dramanın etkililiği. Yaratıcı Drama Dergisi, 3(6), 7-24.

Akyüz, Y. (1979). Eğitimde çocuk-doğa ve çevre korunması ilişkileri. Ankara Üniversitesi Eğitim Bilimleri Fakültesi Dergisi, 12 (1) 85-96.

Artut, K. (2004). Okul öncesi resim eğitiminde çocukların çizgisel gelişim düzeylerine ilişkin bir inceleme. Çukurova Üniversitesi Sosyal Bilimler Enstitüsü Dergisi, 13 (1), 223-234.

Aydın, Ö., \& Aykaç, N. (2016). Yaratıcı drama yöntemi ile verilen eğitimin okul öncesi öğrencilerinin çevre farkındalığına etkisi. Yaratıcı Drama Dergisi, 11(1), 1-16.

Ballantyne, R., \& Packer, J. (2002). Nature-based excursions: School students' perspections of learning in natural environments. International Research in Geographical and Environmental Education, 11(3), 218-236, doi: 10.1080/10382040208667488

Burgess, D. J., \& Mayer-Smith, J. (2011). Listening to children: Perceptions of nature. Journal of Natural History Education And Experience, 5, 27-43.

Chawla, L. (2006). Learning to love the natural world enough to protect it. Barn, 2, 57-78.

Civelek, P., \& Akamca, G. Ö. (2017). Açık alan etkinliklerinin okul öncesi dönemdeki çocukların bilimsel süreç becerilerine ait kazanımlarının gelişimine etkisi. Turkish Studies- International Periodical for the Languages, Literature And History of Turkish or Turkic, 12(18), 173-194.

Creswell, J. W. (2013). Nitel araştırma yöntemleri: Beş yaklaşıma göre nitel araştırma ve araştırma deseni. M. Bütün and S. B. Demir (Çev. Ed.). Ankara: Siyasal Kitabevi.

Çabuk, B. (2001). Okulöncesi dönem çocuklarının çevre ile ilgili farkındalık düzeyleri. (Yayımlanmamış yüksek lisans tezi). Ankara Üniversitesi/Fen Bilimleri Enstitüsü, Ankara.

Çukur, D., \& Özgüner, H. (2008). Kentsel alanda çocuklara doğa bilinci kazandırmada oyun mekânı tasarımının rolü. Süleyman Demirel Üniversitesi Orman Fakültesi Dergisi, 2, 177-187.

Demir, E., \& Yalçın, H. (2014). Türkiye'de çevre eğitimi. Türk Bilimsel Derlemeler Dergisi, 7 (2), 7-18.

Dervişoğlu, S., \& Kılıç, D. S. (2013). Gençlerin doğaya ilişkin değer yönelimleri ve doğa tercihleri. Eğitim ve Ögretim Araştırmaları Dergisi, 2(1), 92-99.

Erentay, N., \& Erdoğan, M. (2009). 22 adımda doğa eğitimi. Ankara: ODTÜ Yayıncılık.

Fargas-Malet, M., Mcsherry, D., Larkin, E., \& Robinson, C. (2010). Research with children: Methodological issues and innovative techniques. Journal of Early Childhood Research, 8(2), 175-192. doi:10.1177/1476718X09345412

Gönen, M., Karakuş, H., Uysal, H., Kehci, A., Ulutaş, Z., \& Kahve, Ö. (2013). Resimli çocuk kitaplarının içerik ve resimleme özelliklerinin bazı değişkenler açısından incelenmesi. Hacettepe Üniversitesi Ĕgitim Fakültesi Dergisi, 31(4), 724-735. doi: 10.16986/HUJE.2015014224

Gülay, H., \& Ekici, G. (2010). MEB Okul öncesi eğitim programının çevre eğitimi açısından analizi. Türk Fen Ë̆itimi Dergisi, 7(1), 74-84.

Gülay, H. (2011). Ağaç yaş iken eğilir: Yaşamın ilk yıllarında çevre eğitiminin önemi. TÜBAV Bilim Dergisi, 4(3), 240-245.

Güler, T. (2009). Ekoloji temelli bir çevre eğitiminin öğretmenlerin çevre eğitimine karşı görüşlerine etkileri. Eğitim ve Bilim, 34(151), 30-43.

Kahyaoğlu, M. (2015). İlköğretim öğrencilerinin doğa kavramına ilişkin algılarının metaforlar yoluyla incelenmesi. Turkish Studies International Periodical for the Languages, Literature and History of Turkish or Turkic, 10 (11), 831-846.

Kahyaoğlu, M. (2016). Türkiye’de doğa eğitimi üzerine yapılan çalışmalarının analizi: Bir meta sentez çalışması. Academia Ë̆itim Araştırmaları Dergisi, 1(1), 1-14.

Kahyaoğlu, M., \& Kırıktaş, H . (2016). Ortaöğretim ve üniversite öğrencilerinin "doğa” kavramına ilişkin algılarının metafor analizi yoluyla incelenmesi. Marmara Coğrafya Dergisi, 33, 58-76. doi: $10.14781 / \operatorname{mcd} .98568$

Keliher, V. (1997) Children's perceptions of nature. International Research in Geographical and Environmental Education, 6(3), 240-243, doi:10.1080/10382046.1997.9965051.

Kesicioğlu, O. S., \& Alisinanoğlu, F. (2009). 60-72 aylık çocukların çevreye karşı tutumlarının çeşitli değişkenler açısından incelenmesi. Ahi Evran Üniversitesi Eğitim Fakültesi Dergisi, 10 (3), 37-48.

Kıldan, O., \& Pektaş, M. (2009). Erken çocukluk döneminde fen ve doğa ile ilgili konuların öğretilmesinde okulöncesi öğretmenlerinin görüşlerinin belirlenmesi. Ahi Evran Üniversitesi Kırşehir Eğitim Fakültesi Dergisi (KEFAD), 10(1), 113-127. 
Köşker, N. (2013). İlkokul öğrencileri ve sınıf öğretmeni adaylarının doğaya ilişkin algıları ve sorumluluklarına yönelik düşünceleri. Turkish Studies International Periodical for the Languages, Literature and History of Turkish or Turkic, 8(3), 341-355.

Köşker, N.,\& Çalışandemir, F. (2015). Child and nature. In R. Efe, C. Bizzarri, İ. Cürebal \& G. N. Nyusupova (Eds.), Environment and ecology at the beginning of 21 st century (pp. 326-336), Sofia: St. Kliment Ohridski University Press.

Kutru, Z., \& Soran, H. (2012). Üniversite öğrencilerinin doğa algıları. X. Ulusal Fen Bilimleri ve Matematik Eğitimi Kongresi, 2-30 Haziran, Niğde. 25.05.2018 tarihinde http://kongre.nigde.edu.tr/ xufbmek/dosyalar/tam_metin/pdf/2439-30_05_2012-20_10_28.pdf adresinden alınmıştır.

Leonard, M. (2006). Children's drawings as a methodological tool: Reflections on the eleven plus system in Northern Ireland. Irish Journal of Sociology, 15(2), 52-66.

Loughland T., Reid A., \& Petocz P. (2002) Young people's conceptions of environment: A phenomenographic analysis. Environmental Education Research, 8 (2), 187-197, doi: 10.1080/13504620220128248

Louv, R. (2010). Doğadaki son çocuk: Çocuklarımızdaki doğa yoksunluğu ve dŏ̆anın să̆altıcı gücü. C. Temürcü (Çev.). Ankara: TÜBITAK Yayınları.

MEB (2013). Okul öncesi eğitim programı. Ankara: Milli Eğitim Bakanlığı Temel Eğitim Genel Müdürlüğü.

Migliarese, N.L. (2008). Researching the child-nature connection. California State Parks. 11.06.2018 tarihinde https://www.parks.ca.gov/pages/24914/files/ adresinden alınmıştır.

Ogelman, H. G. (2012). Teaching preschool children about nature: A project to provide soil education for children in Turkey. Early Childhood Education Journal, 40(3), 177-185.

Onur A., Çağlar, A., \& Salman, M. (2016). 5 yaş okulöncesi çocuklarda atık kâğıtların değerlendirilmesi ve çevre bilincinin kazandırılması. Kastamonu Ĕ̈itim Dergisi, 24(5), 2457-2468.

Ozaner, F. S. (2004). Türkiye'de okul dışı çevre eğitimi ne durumda ve neler yapılmalı? V.Ulusal Ekoloji ve Çevre Kongresi Bildiri Kitabı (ss. 67-98). Bolu: Abant İzzet Baysal Üniversitesi \& Biyologlar Derneği.

Özdemir, P., Akfırat, N., \& Adıgüzel, Ö. (2009). Bilim ve yaratıcı drama eşliğinde doğa eğitimi. Yaratıcı Drama Dergisi, 4(7), 69-78.

Özdemir, O. (2010). Doğa deneyimine dayalı çevre eğitiminin ilköğretim öğrencilerinin çevrelerine yönelik alg1 ve davranışlarına etkisi. Pamukkale Üniversitesi Ĕ̆itim Fakültesi Dergisi, 27, 125-138.

Özgen, N. (2018). Doğa ve toplum. N. Özgen (Ed.) Sosyal Coğrafya içinde (ss: 1-54). Ankara: Pegem Akademi.

Öztürk-Aynal, Ş. (2013). Haydi çocuklar doğaya ve bahçelere açılıyoruz: Mekan dışı eğitim İsveç’ten örnekler. International Journal of Social Science, 6(1), 371-384.

Phenice, L. A., \& Griffore, R. J. (2003). Young children and the natural world. Contemporary Issues in Early Childhood, 4(2), 167-171.

Shepardson, D. P., Wee, B., Priddy, M., \& Harbor, J. (2007). Students' mental models of the environment. Journal of Research in Science Teaching, 44(2), 327-348. doi 10.1002/Tea.20161

Strommen, E. (1995). Lions and tigers and bears, Oh my! Children's conceptions of forests and their inhabitants. Journal of Research in Science Teaching, 32(7), 683-698.

Sungurtekin, Ş. (2001). Uygulamalı çevre eğitimi projesi kapsamında ana ve ilköğretim okullarında müzik yoluyla çevre eğitimi. Uludă̆ Üniversitesi Ĕ̆itim Fakültesi Dergisi, 14(1),167-178.

Şahin, S. , Işıtan, S., \& Ünal, F. (2012). Yerli ve çeviri okulöncesi çocuk kitaplarının karakter, benlik kavramı ve prososyal davranışlar açısından incelenmesi. III. Ulusal Çocuk ve Gençlik Edebiyatı Sempozyumu Bildiri Kitabı. (ss. 1021-1028). 05-07 Ekim 2011. Ankara: Ankara Üniversitesi Çocuk ve Gençlik Edebiyatı Uygulama ve Araştırma Merkezi.

Taşkın, Ö., \& Şahin, B. (2008). Çevre kavramı ve altı yaş okul öncesi çocuklar. Pamukkale Üniversitesi Ĕ̆itim Fakültesi Dergisi, 23, 1-12.

Tosun, N., \& Demir, K. (2018). Minik ayaklar geri dönüyor. Yaratıcı Drama Dergisi, 13(1), 115-128.

Yağc1, M. (2016). Okul öncesi dönem çocuklarının bilimsel süreç becerilerinin gelişmesinde doğa ve çevre uygulamalarının etkisinin incelenmesi. (Yayımlanmamış yüksek lisans tezi). Abant İzzet Baysal Üniversitesi/Eğitim Bilimleri Enstitüsü, Bolu.

Yardımc1, E., \& Kılıç, G.B. (2010). Çocukların gözünden çevre ve çevre sorunları. Elementary Education Online (İlkögretim Online), 9(3), 1122-1136.

Yaşar, M. C., İnal, G., Kaya, Ü. Ü., \& Uyanık, Ö. (2012). Çocuk gözüyle tabiat anaya geri dönüş. Eğitim ve Ögretim Araştırmaları Dergisi, 1(2), 30-40.

Yavuzer, H. (2009). Resimleriyle çocuk: Resimleriyle çocuğu tanıma. İstanbul: Remzi Kitabevi.

Yıldırım, A., \& Şimşek, H. (2008). Sosyal bilimlerde nitel araştırma yöntemleri. Ankara: Seçkin Yayıncılık

Yılmaz-Genç M. M., \& Özen-Uyar, R. (2016). Resimli çocuk kitaplarının fene yönelik kavram, konu ve temalar açısından incelenmesi. Uluslararası Sosyal Araştırmalar Dergisi, 9(46), 600-607. 


\section{EXTENDED ABSTRACT}

\section{Introduction}

Education has an important role in developing an ecological awareness of nature. The nature education to be conducted to educate individuals with an ecological awareness is expected to shape the attitudes and behaviors of individuals. In this regard, the first step should be to determine individuals' perceptions of nature. The individual's perception of the world in which he/she is living provide the basis for his/her attitudes and behaviors. The relationships created with the outer world by the individual and his/her experiences play a very significant role in the formation of his/her perceptions. From the birth onwards, the experiences lived by the individual in the cultural and natural environment in which he/she lives have an important role in shaping his/her attitudes and behaviors. At early ages, the positive experiences lived by the individual about himself/herself, his/her surroundings and nature will form the basis of the way of how he/she will assess the world (Kesicioğlu and Alisinanoğlu, 2009). In this context, early childhood emerges as a critical period in which a number of attitudes and behaviors are formed that will carry the individual from childhood to adulthood and which is of critical importance for the cognitive, affective and social development of the individual. Early childhood is a period full of experiences through which children acquire basic concepts and scientific process skills. Experiences lived by children during this period create a suitable environment for the acquisition of concepts that are considered building blocks of knowledge (K1ldan and Pektaş, 2009). It is known that children can learn faster and better in settings where they can see, touch, hear; thus, make use of their senses and can wonder, observe and test (Erentay and Erdoğan, 2009). Out of classroom settings in this regard provide important opportunities for learning.

Delivery of the nature education at school as it is today seems to be insufficient as it does not include any application within the real life (Çukur and Özgüner, 2008). It is not feasible to carry out a training aimed at ecological awareness with the object-oriented, non-experiential teaching activities through images rather than nature itself as restricted within the school. Learning of natural elements and the relationships between them by the child depends on his/her getting to know nature. In an education to be carried out in nature, the experiences gained by using all the senses will bring awareness to the child and then it will turn into attitudes and behaviors that will form the basis of ecological consciousness. Interaction with nature at an early age leads to positive results in terms of healthy development of the child as well as of the awareness, commitment and ecological responsibility towards nature (Ballantyne and Packer, 2002; Chawla, 2006; Civelek and Akamca, 2017; Keliher, 1997; Louv, 2010; Özdemir, 2010). In this connection, determination of children's perceptions of nature will provide important opportunities for the design and implementation of an educational process integrated with nature that will raise the ecological awareness of children.

The current study aimed to determine the pre-school children's perceptions of nature. To this end, answers to the following questions were sought:

1. How do the pre-school children perceive the concept of nature?

2. How do the pre-school children define the elements in nature?

3. What are the pre-school children's experiences of nature?

\section{Method}

As the current study aimed to determine the children's perceptions of nature in detail, it was designed as a qualitative study. The study group of the current study is comprised of 100 children attending pre-schools in the city of Kirkkale in 2016-2017 school year. In the determination of the study group, the purposive sampling method was employed and the children at the age of six were included in the study considering their both expression skills and perception levels.

In order to collect data in the current study, the nature paintings drawn by the children and the semi-structured interview technique were used. The interview data and the paintings drawn by the children were analyzed by using content analysis. The analysis of the collected data were performed by two researchers and then checked through comparison. The coded data are presented as themes and categories with frequencies and percentages. In the presentation of the findings, examples from the children's statements and drawings are also given.

\section{Findings, Discussion and Results}

It was determined that the children frequently depicted non-living things in their drawings. The most frequently depicted elements of nature were found to be the Sun and clouds. Under the theme of living things, the most frequently depicted elements were found to be trees, flowers and grass. The findings related to the children's 
definition of nature revealed that the children most frequently used animals and plants to define nature. Among the plants, tree $(\mathrm{f}=66)$ and flower $(\mathrm{f}=47)$ were found to have the highest frequencies.

During the interviews with the children, the most frequently emphasized category by the children was found to be animals. It was found that while the children did not include animals in their drawings, they frequently mentioned animals during the interviews. The theme of animals has the highest frequency in the children' definitions of nature and natural elements. Of the animals mentioned by the children to be found in nature, $39.2 \%(\mathrm{f}=102)$ are wild animals that they cannot see around.

In the study, it was found that $97 \%$ of the children have a perception of nature centered on concrete objects. Similarly, Taşkın and Şahin (2008) also found that the participating children see objects such as trees, flowers, birds etc. in their environment and use them in their drawings; yet, cannot explain the relationships between these objects. This might be because of the perception levels of the students at this age. On the other hand, their inability of expressing even simple relationships (for example, the relationships between plants, soil, animals and humans) points to the inadequacy of observations and experiences that can enhance their levels of perception.

In the statements related to the definitions of nature and elements in nature, majority of the children did not mention the element of human. In the study by Phenice and Griffore (2003), it was found that the children perceive trees, animals, and plants to the greatest extent as part of nature and humans to the smallest extent. For $82 \%$ of the children, nature is the place distant from where they live. Of the children stating that they have not been in nature, $83.5 \%$ and of the children stating that they have been in nature, $78.7 \%$ think that nature is somewhere distant.

While $89 \%$ of the children stated that they want to be in nature and love it, $11 \%$ stated that they do not want to be in nature. Of the children wanting to be in nature and loving it, $19.1 \%$ related nature mostly to entertainment (play, picnic, camp, holiday); 13.4\% made no explanation. This indicates that the children's experiences of nature are inadequate or limited. The children stating that they don't want to be in nature presented the fear of wild animals as the reason.

Early childhood is a critical time for the inculcation of the love and consciousness of nature. In this period, nature education activities to be conducted outside the class and school will help children perceive nature and diversity in nature in a context and develop the awareness and love of nature. Therefore, out of class and school activities should be incorporated into pre-school curriculums in cognitive, affective and kinesthetic domains. Thus, nature can be perceived as a place which is known, understood and experienced rather than a distant place. 